\title{
PENILAIAN KINERJA KEUANGAN PERUSAHAAN MENGGUNAKAN METODE ECONOMIC VALUE ADDED DI PT. KRAKATAU STEEL TBK TAHUN 2014-2018
}

\author{
Luki Malikul Malik ${ }^{1}$ \\ Program Studi Public Relation, Sekolah Tinggi Ilmu Komunikasi, London School \\ email: lukizenit@gmail.com
}

Korespondensi : lukizenit@gmail.com

\begin{abstract}
This research aims to determine the financial performance of PT. Krakatau Steel (Persero) which is Tbk calculated from 2014 to 2018 using the Economic Value Added (EVA) Method. Based on these objectives, this study used descriptive statistical analysis methods using secondary data. The results showed that the value of EVA company is <0 or in other words the value is negative so it can be concluded that the financial company for five years, 2014 2018, was included in the unfavorable category.
\end{abstract}

Keywords: financial performance, financial statements, eva, performance assessment, pt krakatau

\begin{abstract}
Abstrak
Penelitian ini bertujuan untuk mengetahui kinerja keuangan PT. Krakatau Steel (Persero) Tbk yang dihitung dari tahun 2014 sampai tahun 2018 dengan menggunakan Metode Economic Value Added atau disingkat EVA. Berdasarkan tujuan tersebut, penelitian ini menggunakan metode analisis statistic deskriptif dengan menggunakan data sekunder. Hasil penelitian menunjukan bahwa nilai EVA adalah $<0$ atau dengan kata lain nilainya negatif, sehingga dapat disimpulkan bahwa kinerja keuangan perusahaan selama lima tahun yaitu 2014-2018 termasuk ke dalam kategori kurang baik.
\end{abstract}

Kata kunci: kinerja keuangan, laporan keuangan, eva, penilaian kinerja, pt krakatau

\section{PENDAHULUAN}

Pada dasarnya pendirian sebuah perusahaan bertujuan untuk mendapatkan keuntungan dengan memperoleh laba, memaksimalkan nilai saham, melalui peningkatan penjualan. Akan tetapi perusahan dihadapkan pada dinamika dunia usaha yang terus berubah dalam menjalankan kegiatan perekonomiannya. Oleh karena itu, untuk dapat bertahan dalam gejolak perekonomian dan dinamika dunia bisnis, perusahaan harus memiliki kinerja keuangan yang baik melalui peningkatan penjualan.

Perusahaan dengan kinerja keuangan yang baik tidak hanya dapat menjaga keberlangsungan bisnisnya, namun juga dapat menarik investor untuk berinvestasi. Kinerja keuangan perusahaan harus dinilai secara rutin dan berkala. Penilaian 
keuangan dimaksudkan untuk mengevaluasi sejauh mana kinerja yang dilakukan oleh perusahaan telah mencapai tujuannya yaitu mendapatkan keuntungan, menjaga keberlangsungan perusahaan serta mensejahterakan karyawannya. Berkaitan dengan hal tersebut, penting bagi perusahaan untuk menerapkan fungsi manajemen keuangan dalam menilai kinerja keuangan. Pada dasarnya kinerja keuangan merupakan sebuah analisis yang bertujuan untuk menilai sejauh mana aturan-aturan perusahaan telah dijalankan sesuai dengan aturan pelaksanaan keuangan (Fahmi, 2013).

Setiap perusahaan memiliki indicator kinerja keuangan yang beragam dan mungkin berbeda dengan perusahaan lainnya. Hal tersebut berhubungan dengan karakteristik perusahaan serta proses bisnisnya. Akan tetapi secara umum, analisis rasio keuangan digunakan oleh banyak perusahaan dalam mengukur kinerja keungannya. Meskipun demikian, analisis rasio keuangan sulit untuk mengukur rasio kepentingan stakeholder. Rasio keuangan pada umumnya digunakan untuk menilai kinerja keuangn yang hanya berorientasi pada profit namun tidak dapat mengukur value. Berkaitan dengan kelemahan rasio keuangan tersebut, Economic Value Added merupakan metode yang direkomendasikan dalam melakukan penilaian kinerja keuangan secara lebih komprehensif (Altaf, 2016).

Keunggulan dari metode Economic Value Added adalah dapat menentukan sejauh mana sebuah investasi memberikan kontribusi positif terhadap kekayaan pemegang saham (Sawir, 2009). Economic Value Added dapat mengakomodasi kepentingan serta harapan-harapan para pemegang saham dan kreditur. Mekanisme Economic Value Added dalam mengukur kinerja keuangan adalah dengan mengurangkan laba setelah pajak dengan biaya tahunan dari semua modal yang digunakan perusahaan. Pada intinya, Economic Value Added diterapkan untuk penciptaan nilai perusahaan. Melalui pendekatan Economic Value Added para pemegang saham dapat melihat seberapa besar perusahaan meraih nilai tambah.

PT Krakatau Steel (Persero) Tbk merupakan perusahaan di bawah naungan BUMN yang bergerak di bidang manufaktur yang berdiri pada 31 agustus 1970 dalam masa pemerintahan presiden Soeharto yang berlokasi di Cilegon, Banten dan PT Krakatau Steel (Persero) Tbk berperan sebagai produsen barang- barang industri terbesar di Indonesia. Perusahaan tersebut memproduksi barang- barang industri seperti besi, baja, pipa spiral dan lain-lain yang nantinya tidak hanya ditujukan untuk kebutuhan baja nasional saja, namun dipasarkan ke dalam pasar internasional juga. Akan tetapi berdasrkan laporan keuangan PT Krakatau Steel (Persero) Tbk tahun 2014-2018, perusahaan terus mengalami kerugian. Hal tersebut tentu berdampak pada reputasi perusahaan yang dinilai buruk dalam meraih laba. Berdasarkan permasalahan tersebut, perusahaan perlu melakukan evaluasi kinerja keuangan perusahaan dengan menggunakan metode Economic Value Added.

\section{Analisis Laporan Keuangan}

Analisis laporan keuangan merupakan sebuah aktivitas menjabarkan pos-pos laporan keuangan menjadi unit informasi yang lebih kecil dan melihat signifikansi hubungan satu dengan yang lain baik secara kuantitatif maupun non kuantitatif. Tujuan dari analisis laporan keuangan adalah untuk mengetahui kondisi keuangan 
dalam rangka pembuatan keputusan (Harahap, 2013). Secara mendetail, Harahap (2013) menjabarkan tujuan analisis laporan keuangan sebagai berikut:

1. Screening yaitu analisis bertujuan untuk memilih keumungkinan investasi atau merger.

2. Forcasting yaitu analisis digunakan untuk meramal kondisi keungan perusahaan di masa depan.

3. Diagnosis yaitu analisis digunakan untuk melihat kemungkinan adanya masalah-masalah yang terjadi baik dalam manajemen operasi, keuangan atau persoalan lainnya.

4. Evaluation yaitu menggunakan analisis untuk menilai prestasi manajemen, operasional, efisiensi dan lain-lain.

\section{Kinerja Keuangan}

Kinerja keuangan secara umum diukur dari pengahasilan bersih atau laba atau dari ukuran lain yaitu imbalan investasi, atau penghasilan per saham (Harmono, 2009). Berbeda dengan pendapat tersebut, Fahmi (2013) berpendapat bahwa kinerja keuangan merupakan analysis yang bertujuan untuk melihat sejauh mana aturanaturan keuangan diimplementasikan dengan baik dan benar oleh perusahaan.

\section{Economic Value Added (EVA)}

Economic Value Added atau disingkat EVA merupakan sebuah cara atau metode yang digunakan untuk menilai kinerja keuangan yang dilihat dari adanya penambahan nilai suatu investasi (Sawir, 2009). Mekanisme metode EVA adalah dengan mengurangi laba bersih dengan total biaya tahunan. EVA merupakan residu dengan biaya modal sama dengan biaya actual dari perusahaan. Apabila EVA bernilai positif maka perusahaan sedang menciptakan kekayaan, sebaliknya apabila EVA negative maka terdapat modal yang disia-siakan oleh perusahaan. Melalui metode EVA, perusahaan dapat menilai perbandingan antara jumlah uang yang didapatkan dengan uang yang dikeluarkan untuk mendapatkan keuntungan. Analisis tersebut dapat menentukan ketahanan dan keberlangungan perusahaan dalam mendapatkan modal dan kekayaan (Hansen dan Mowen, 2009).

Selanjutnya menurut Brigham dan Houston (2011), EVA merupakan estimasi laba ekonomi usaha untuk tahun tertentu dan sangat berbeda jauh dengan laba bersih akuntansi di mana laba tidak dikurangi dengan biaya ekuitas. Sedangkan dalam EVA biaya tersebut akan dikeluarkan. Menurut Tunggal (2008), perusahaan dapat dikatakan sejahtera apabila semua biaya operasi dan biaya modal terpenuhi.

\section{Tujuan dan Manfaat Penerapan Metode Economic Value Added}

Penerapan EVA bertujuan untuk mendapatkan hasil perhitungan yang lebih realistis. Hal tersebut dapat dicapai karena EVA dihitung berdasarkan perhitungan biaya modal yang menggunakan nilai pasar berdasarkan kepentingan kreditur terutama para pemegang saham, bukan berdasarkan nilai buku. Manfaat lain dari perhitungan EVA adalah untuk menyajikan laporan keuangan yang lebih mudah dipahami oleh para stakeholder antara lain investor, kreditur, karyawan, pemerintah, pelanggan dan pihak-pihak berkepentingan lainnya (Abdullah, 2010). 


\section{METODE PENELITIAN}

\section{Jenis dan Sumber Data}

Data yang digunakan adalah data kualitatif yaitu data-data yang bukan dalam bentuk angka, dan data kuantitatif yaitu data yang diukur dalam skala numerik. Data kuantitatif pada penelitian ini adalah laporan keuangan PT. Krakatau Steel 2014-2018.

Adapun sumber data diperoleh dari sumber sekunder yang dikumpulan oleh Lembaga pengumpul data dan dipublikasikan kepada masyarakat dan pengguna data (Kuncoro, 2009). Data sekunder dalam penelitian ini diperoleh dari laporan keuangan PT Krakatau Steel tahun 2014-2018.

\section{Metode Analisis Data}

Metode analisis data yang digunakan adalah statistic deskriptif yaitu statistic yang dugunakan untuk menganalisis data dengan cara mendeskripsikan atau menggambarkan data yang telah terkumpul. Alat analisis yang digunakan adalah Economic Value Added dengan langkah-langkah sebagai berikut.

\section{Menghitung Economic Value Added.}

Adapun rumus yang digunakan adalah:

$$
E V A=\text { NOPAT }-(\text { WACCXInvested Capital })
$$

Keterangan:

EVA

NOPAT

WACC

Invested Capital
$=$ Economic Value Added

$=$ Net Operating Profit After Tax

$=$ Weighted Average Cost of Capital

$=$ Modal yang diinvestasikan

\section{Menentukan Net Operating Profit After Tax (NOPAT)}

Rumus yang digunakan adalah:

$$
\text { Nopat }=\operatorname{EBIT}(1-T)
$$

Keterangan

$\begin{array}{ll}\text { NOPAT } & =\text { Net Operating Profit After Tax } \\ \text { EBIT } & =\text { Earnings Before Interest and Tax } \\ \mathrm{T} & =\text { Tingkat Pajak }\end{array}$

\section{Biaya Modal (Capital Charges)}

Rumus yang digunakan adalah:

Biaya Modal $($ Capital Charges $)=$ WACCxInvested Capital

WAAC Dihitung dengan rumus: 
$W A C C=W_{d} K_{d}+W_{e} K_{e}$

$W_{d}=\frac{\text { Total Hutang }}{\text { Total Hutang }+ \text { Ekuitas }}$

$W_{e}=\frac{\text { Total Ekuitas }}{\text { Total Hutang }+ \text { Ekuitas }}$

Keterangan:

WACC $=$ Weighted Average Cost of Capital

$\mathrm{Wd} \quad=$ Jumlah Hutang terhadap Struktur Modal

We = Jumlah Modal terhadap struktur modal

$\mathrm{Kd}=$ Cost of Debt

$\mathrm{Ke} \quad=$ Cost of Equity

Biaya Utang (Cost of Debt)

Biaya hutang dihitung dengan rumus:

$k_{d}=k_{d b t}(1-T)$

$k_{\text {dbt }}=\frac{\text { Beban Bunga }}{\text { Utang Jangka Panjang }}$ )

$T($ Tingkat Pajak $\left.)=\frac{\text { Beban Bunga }}{\text { Utang Jangka Panjang }}\right)$

Keterangan

$\mathrm{Kd}$

= Biaya hutang setelah pajak

Kdbt = Tingkat bunga biaya utang sebelum pajak

$\mathrm{T}=$ Tingkat pajak

Biaya Ekuitas

Biaya ekuitas atau Cost of Equity diperoleh dengan menggunakan Return of Equity (ROE) yang dihitung dengan rumus:

$K e=R O E=\frac{\text { Laba Bersih Setelah Pajak }}{\text { Total Ekuitas }}$

Modal yang diinvestasikan

Modal yang diinvestasikan dihitung dengan rumus:

Modal yang diinvestasikan = Utang Jangka Panjang + Ekuitas Pemegang saham 


\section{HASIL ANALISIS \\ Analisis NOPAT}

Menghitung NOPAT merupakan tahapan pertama yang harus dilakukan dalam perhitungan EVA. Menurut Brigham dan Houston, 2010) NOPAT merupakan keuntungan bersih dari operasi perusahaan setelah pajak.

Selanjutnya, hasil perhitungan NOPAT ditunjukan pada tabel 1.

Tabel 1. NOPAT PT. Krakatau Steel (Persero) Tbk Tahun 2014-2018 (dinyatakan dalam ribuan dolar)

\begin{tabular}{|l|c|c|c|c|c|}
\hline Komponen & $\mathbf{2 0 1 4}$ & $\mathbf{2 0 1 5}$ & $\mathbf{2 0 1 6}$ & $\mathbf{2 0 1 7}$ & $\mathbf{2 0 1 8}$ \\
\hline EBIT & -70.854 & -183.549 & 4.390 & 50.744 & -3.318 \\
\hline Beban Pajak & -35.928 & -6.799 & -14.375 & 3.755 & -4.237 \\
\hline Laba sebelum pajak & -190.113 & -333.313 & -195.099 & -82.342 & -81.400 \\
\hline Tax & $14,19 \%$ & $2,04 \%$ & $7,36 \%$ & $-4,56 \%$ & $5,21 \%$ \\
\hline 1-Tax & 0,86 & 0,98 & 0,92 & 1,05 & 0,95 \\
\hline NOPAT & -60.934 & -179.878 & 4.039 & 53.058 & -3.145 \\
\hline
\end{tabular}

Dari data pada tabel 1 terlihat bahwa nilai NOPAT pada tahun 2014 nilai NOPAT adalah US\$ -60.934 .000 dan pada tahun 2015 nilai NOPAT tersebut mengalami penurunan signifikan yaitu menjadi US\$ -179.878 .000 yang disebabkan oleh adanya penurunan EBIT. Selanjutnya pada tahun 2016 nilai NOPAT mengalami peningkatan menjadi US\$ 4.039.000 dan nilai tersebut terus meningkat pada tahun 2017 menjadi US\$ 53.058.000. Akan tetapi pada tahun 2018 terjadi penurunan signifikan menjadi US\$ -3.145 .000 yang disebabkan oleh adanya penurunan nilai EBIT. Berdasarkan data tersebut dapat disimpulkan bahwa nilai NOPAT dari tahun 2014 hingga tahun 2018 mengalami fluktuatif namun pada akhir tahun 2018 mengalami penurunan signifikan.

\section{Analisis WACC (Weight Average Cost of Capital)}

Perhitungan WACC atau Weight Average Cost of Capital merupakan tahapan selanjutnya yang harus dilakukan setelah menghitung nilai NOPAT untuk analisis EVA. Selanjutnya hasil perhitungan WACC disajikan dalam tabel 2.

Tabel 2. WACC PT. Krakatau Steel (Persero) Tbk Tahun 2014-2018 (dinyatakan dalam ribuan dolar)

\begin{tabular}{|l|c|c|c|c|c|}
\hline & $\mathbf{2 0 1 4}$ & $\mathbf{2 0 1 5}$ & $\mathbf{2 0 1 6}$ & $\mathbf{2 0 1 7}$ & $\mathbf{2 0 1 8}$ \\
\hline Beban Bunga & 51.470 & 88.332 & 127.651 & 99.288 & 112.334 \\
\hline Liabilities Jangka Panjang & 305.129 & 448.788 & 872.535 & 899.672 & 899.430 \\
\hline Tax & $14,19 \%$ & $2,04 \%$ & $7,36 \%$ & $-4,56 \%$ & $5,21 \%$ \\
\hline $1-$ Tax & 0,86 & 0,98 & 0,92 & 1,05 & 0,95 \\
\hline $\mathrm{Kd} / \mathrm{ROE}$ & $14,51 \%$ & $19,29 \%$ & $13,46 \%$ & $11,54 \%$ & $11,84 \%$ \\
\hline $\mathrm{Ke}$ & $-6,88 \%$ & $-10,06 \%$ & $0,22 \%$ & $2,86 \%$ & $-0,17 \%$ \\
\hline
\end{tabular}




\begin{tabular}{|l|c|c|c|c|c|}
\hline Total Hutang & 1.718 .424 & 1.914 .115 & 2.097 .036 & 2.261 .577 & 2.498 .105 \\
\hline Total Ekuitas & 885.933 & 1.788 .029 & 1.839 .677 & 1.852 .809 & 1.800 .213 \\
\hline Total Hutang+Total Ekuitas & 2.604 .357 & 3.702 .144 & 3.936 .713 & 4.114 .386 & 4.298 .318 \\
\hline$W d$ & $65,98 \%$ & $51,70 \%$ & $53,27 \%$ & $54,97 \%$ & $58,12 \%$ \\
\hline$W e$ & $34,02 \%$ & $48,30 \%$ & $46,73 \%$ & $45,03 \%$ & $41,88 \%$ \\
\hline Laba bersih setelah pajak & -154.185 & -326.514 & -180.724 & -86.097 & -77.163 \\
\hline ROE & $-17,40 \%$ & $-18,26 \%$ & $-9,82 \%$ & $-4,65 \%$ & $-4,29 \%$ \\
\hline WACC & $7,23 \%$ & $5,11 \%$ & $7,27 \%$ & $7,63 \%$ & $6,81 \%$ \\
\hline
\end{tabular}

Dari data yang disajikan dalam tabel 2, dapat dilihat bahwa nilai WACC PT. Krakatau Steel pada tahun 2014 adalah 7,23\% dan pada tahun 2015 mengalami penurunan menjadi $5,11 \%$ yang disebabkan adanya penurunan ROE. Pada tahun 2016 nilai WACC tersebut mengalami peningkatkan yaitu $7,27 \%$ dan terus meningkat hingga tahun 2017 yaitu menjadi 7,63\%. Akan tetapi pada tahun 2018 nilai WACC mengalami penurunan yaitu menjadi $6,81 \%$ yang disebabkan oleh adanya penurunan ROE. Dari data tersebut terlihat bahwa nilai WACC PT Krakatau Steel dari 2014-2018 mengalami fluktuatif namun melihat dari adanya penurunan pada tahun 2018 menunjukan bahwa perusahaan telah berhasil menurunkan rata-rata tertimbang sehingga dapat membantu menghasilkan EVA Positif (Subedi, 2020).

\section{Analisis Invested Capital}

Tahapan selanjutnya dalam melakukan analisis EVA adalah menghitung modal yang diinvestasikan (Hefrizal, 2018). Data modal yang diinvestasikan PT Krakatau Steel tahun 2014-2018 disajikan dalam tabel 3 berikut.

Tabel 3. Invested Capital PT. Krakatau Steel (Persero) Tbk Tahun 2014-2018 (dinyatakan dalam ribuan Dolar)

\begin{tabular}{|l|c|c|c|c|c|}
\hline & $\mathbf{2 0 1 4}$ & $\mathbf{2 0 1 5}$ & $\mathbf{2 0 1 6}$ & $\mathbf{2 0 1 7}$ & $\mathbf{2 0 1 8}$ \\
\hline Hutang Jangka Panjang & $\mathbf{3 0 5 . 1 2 9}$ & $\mathbf{4 4 8 . 7 8 8}$ & $\mathbf{8 7 2 . 5 3 5}$ & $\mathbf{8 9 9 . 6 7 2}$ & $\mathbf{8 9 9 . 4 3 0}$ \\
\hline Ekuitas & $\mathbf{8 8 5 . 9 3 3}$ & $\mathbf{1 . 7 8 8 . 0 2 9}$ & $\mathbf{1 . 8 3 9 . 6 7 7}$ & $\mathbf{1 . 8 5 2 . 8 0 9}$ & $\mathbf{1 . 8 0 0 . 2 1 3}$ \\
\hline Invested Capital & $\mathbf{1 . 1 9 1 . 0 6 2}$ & $\mathbf{2 . 2 3 6 . 8 1 7}$ & $\mathbf{2 . 7 1 2 . 2 1 2}$ & $\mathbf{2 . 7 5 2 . 4 8 1}$ & $\mathbf{2 . 6 9 9 . 6 4 3}$ \\
\hline
\end{tabular}

Hasil penelitian menunjukan bahwa pada tahun 2014 modal yang diinvestasikan adalah US\$1.191.062.000 dan nilai tersebut mengalami peningkatan pada tahun 2016 menjadi US\$ 2.236.817.000. Pada tahun 2016 modal yang diinvestasikan terus mengalami peningkatan menjadi 2.712 .212 .000 begitupun di tahun 2017 yang juga mengalami peningkatan yaitu menjadi 2.752.481. Akan tetapi pada tahun 2018 modal yang diinvesatsikan mengalami penurunan yaitu menjadi 2.699.643.000. Berdasarkan data tersebut terlihat bahwa selama tahun 2015 hingga tahun 2017 modal yang diinvestasikan mengalami peningkatan namun pada tahun 2018 mengalami penurunan yang disebabkan oleh penurunan jumlah pinjaman maupun ekuitas pemegang saham. 


\section{Analisis EVA}

Setelah semua tahapan dilakukan, maka dilakukan perhitungan EVA. Hasil perhitungan selanjutnya disajikan dalam tabel 4 sebagai berikut :

Tabel 4. Nilai EVA Krakatau Steel (Persero) Tbk Tahun 2014-2018 (dinyatakan dalam ribuan dollar)

\begin{tabular}{|l|c|c|c|c|c|}
\hline & $\mathbf{2 0 1 4}$ & $\mathbf{2 0 1 5}$ & $\mathbf{2 0 1 6}$ & $\mathbf{2 0 1 7}$ & $\mathbf{2 0 1 8}$ \\
\hline NOPAT & $\mathbf{- 6 0 . 9 3 4}$ & $\mathbf{- 1 7 9 . 8 7 8}$ & $\mathbf{4 . 0 3 9}$ & $\mathbf{5 3 . 0 5 8}$ & $\mathbf{- 3 . 1 4 5}$ \\
\hline WACC & $\mathbf{7 , 2 3 \%}$ & $\mathbf{5 , 1 1 \%}$ & $\mathbf{7 , 2 7 \%}$ & $\mathbf{7 , 6 3 \%}$ & $\mathbf{6 , 8 1 \%}$ \\
\hline Invested Capital & $\mathbf{1 . 1 9 1 . 0 6 2}$ & $\mathbf{2 . 2 3 6 . 8 1 7}$ & $\mathbf{2 . 7 1 2 . 2 1 2}$ & $\mathbf{2 . 7 5 2 . 4 8 1}$ & $\mathbf{2 . 6 9 9 . 6 4 3}$ \\
\hline Biaya Modal WACC $x$ IC) & $\mathbf{8 6 . 1 4 0}$ & $\mathbf{1 1 4 . 3 9 2}$ & $\mathbf{1 9 7 . 2 4 0}$ & $\mathbf{2 1 0 . 0 8 1}$ & $\mathbf{1 8 3 . 7 8 2}$ \\
\hline $\boldsymbol{E V A}$ & $\mathbf{- 1 4 7 . 0 7 4}$ & $\mathbf{- 2 9 4 . 2 7 0}$ & $\mathbf{- 1 9 3 . 2 0 1}$ & $\mathbf{- 1 5 7 . 0 2 3}$ & $\mathbf{- 1 8 6 . 9 2 8}$ \\
\hline
\end{tabular}

Hasil perhitungan EVA menunjukan bahwa pada tahun 2014 nilai EVA PT Krakatau Steel adalah US\$ -147.074.000. Jumlah tersebut mengalami penurunan pada tahun 2015 menjadi US\$ -294.270.000 dan pada tahun 2016 menjadi US\$ 193.201.000. Pada tahun 2017 nilai EVA mengalami peningkatan menjadi US\$ 157.023.000 dan pada tahun 2018 kembali menurun menjadi US\$ -186.928.000. Berdasarkan hasil perhitungan tersebut terlihat bahwa walaupun terjadi peningkatan pada akhir tahun 2018 dibandingkan tahun 2017, namun secara keseluruhan dari tahun 2014 hingga tahun 2018 nilai EVA $<0$ maka nilai EVA bernilai negative. Nilai EVA yang negative tersebut merupakan sebuah indikasi bahwa perusahaan belum mampu menciptakan nilai tambah baik bagi perusahaan maupun bagi pemegang saham.

\section{PEMBAHASAN}

Penelitian kinerja diukur menggunakan metode Economic Value Added (EVA) yang bertujuan untuk mengukur kinerja perusahaan tidak hanya dari sisi laba namun mengukur seberapa jauh kinerja perusahaan telah memberikan kontrbusi nilai bagi pemegang saham (Salaga et al, 2015). Selanjutnya, ringkasan data hasil perhitugan EVA disajikan dalam tabel 5 dan diilustrasikan dalam gambar 1 .

Tabel 5. Ringkasan Kinerja PT. Krakatau Steel (Persero) Tbk Tahun 2014-2018 (dinyatakan dalam ribuan dollar)

\begin{tabular}{|l|c|c|c|c|c|}
\hline Keterangan & $\mathbf{2 0 1 4}$ & $\mathbf{2 0 1 5}$ & $\mathbf{2 0 1 6}$ & $\mathbf{2 0 1 7}$ & $\mathbf{2 0 1 8}$ \\
\hline NOPAT & $\mathbf{- 6 0 . 9 3 4}$ & $\mathbf{- 1 7 9 . 8 7 8}$ & $\mathbf{4 . 0 3 9}$ & $\mathbf{5 3 . 0 5 8}$ & $\mathbf{- 3 . 1 4 5}$ \\
\hline Biaya Modal & $\mathbf{8 6 . 1 4 0}$ & $\mathbf{1 1 4 . 3 9 2}$ & $\mathbf{1 9 7 . 2 4 0}$ & $\mathbf{2 1 0 . 0 8 1}$ & $\mathbf{1 8 3 . 7 8 2}$ \\
\hline EVA & $\mathbf{- 1 4 7 . 0 7 4}$ & $\mathbf{- 2 9 4 . 2 7 0}$ & $\mathbf{- 1 9 3 . 2 0 1}$ & $\mathbf{- 1 5 7 . 0 2 3}$ & $\mathbf{- 1 8 6 . 9 2 8}$ \\
\hline
\end{tabular}




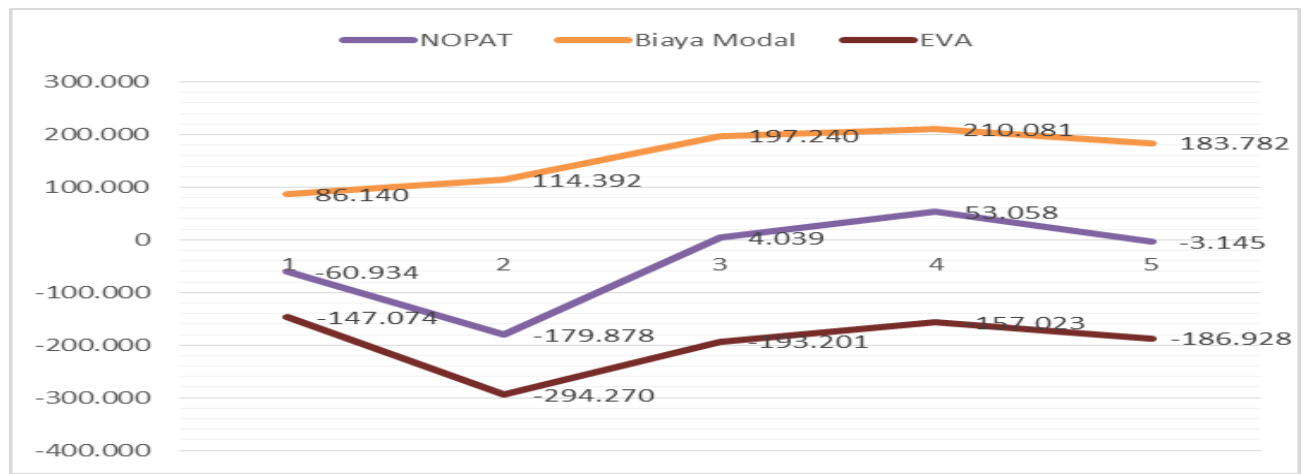

Gambar 1. Ringkasan Kinerja PT. Krakatau Steel (Persero) Tbk Tahun 2014-2018 (dinyatakan dalam ribuan dollar)

Berdasrkan hasi perhitungan terlihat bahwa dari kurun waktu tahun 2014 hingga tahun 2018 nilai NOPAT, nilai modal dan nilai EVA mengalami fluktuasi. Untuk nilai NOPAT terlihat bahwa pada tahun 2015 terdapat penurunan signifikan yanitu mencapai US\$ -179.878. Selanjutnya nilai NOPAT tersebut mengalami peningkatan yang cukup signifikan pada tahun 2016 menjadi US\$ 4.039 dan pada tahun 2017 menjadi US\$ 53.058. Akan tetapi pada tahun 2018 terjadi penurunan nilai NOPAT menjadi US\$ -3.145 . Berdasarkan hasil tersebut terlihat bahwa fluktuasi nilai NOPAT yang tajam merupakan indikasi nilai laba operasi perusahaan belum stabil. Penurunan terburuk terjadi pada 2015, sedangkan pencapain terbaik terjadi pada tahun 2017 meskipun kembali mengalami penurunan pada tahun 2018. Melihat nilai NOPAT yang tidak stabil dan terjadi penuruhan, perusahaan perlu untuk menjaga stabilitas penjualan dan investasi. Selanjutnya, dilihat dari biaya modal terlihat bahwa dari tahun 2014 hingga tahun 2018 biaya modal terus mengalami peningkatan dan hanya pada tahun 2018 biaya modal tersebut mengaami penurunan. Dari hasil tersebut terlihat bahwa biaya modal yang dikelurkan masih jauh lebih besar dibandingkan nilai NOPAT atau laba operasi setelah pajak. Kondisi tersebut dapat menjadi penyebab nilai EVA yang negatif. Dilihat dari nilai EVA, secara keselurunan dari kurun waktu tahun 2014 hingga tahun 2015 nilai EVA negatif. Penurunan paling signifikan terjadi pada tahun 2015, dan walaupun terjadi peningkatan dari tahun 2016 ke tahun 2018 namun pada akhir tahun 2018 kembali terjadi penurunan. Negatifnya nilai EVA terebut menunjukan menciptakan nilai EVA yang positif. Melihat nilai EVA yang masih negative, perusahaan perlu meningkatkan nilai laba operasi tanpa adanya tambahan modal. Apabila nilai laba operasi meningkat maka nilai EVA akan meningkat walaupun biaya modal tetap.

\section{SIMPULAN DAN SARAN Simpulan}

Berdasarkan hasil penelitian dan pembahasan maka dapat ditarik simpulan sebagai berikut:

1. Berdasarkan analisis Economic Value Added (EVA) selama lima tahun terakhir yaitu dari tahun 2014-2018 kinerja keuangan PT. Krakatau Steel masih 
dikategorikan kurang baik. Hal tersebut terlihat dari nilai EVA yang masih negative.

2. Nilai EVA lebih kecil dari 0 atau bernilai negatif. Negatifnya nilai EVA tersebut merupakan indikasi perusahaan belum mampu menghasilkan tingkat pengembalian laba setelah pajak yang lebih besar dari biaya modal. Kondisi ini membuat perusahaan belum mampu menciptakan nilai tambah baik bagi perusahaan maupun bagi investor

\section{Saran}

Berdasarkan simpulan, perusahaan disarankan untuk meningkatkan nilai EVA dengan mengurangi hutang serta menegosiasikan suku bunga dan melakukan pengawasan secara ketat terhadap penggunaan biaya modal.

\section{DAFTAR PUSTAKA}

Altaf, Nufazil. (2016. Economic value added or earnings: What explains market value in Indian firms?. Future Business Journal, Volume 2, Issue 2. Pages 152-166. https://doi.org/10.1016/j.fbj.2016.11.001.

Brigham, Eugene dan Joel F. Houston. (2010). Manajemen Keuangan. Jakarta: Erlangga.

Fahmi, Irham. (2013). Analisis Laporan Keuangan. Bandung: Alfabeta.

Harahap, Sofyan Safri. (2013). Analisis Kritis Atas Laporan Keuangan. Jakarta: Raja Grafindo Persada.

Harmono. (2009). Manajemen Keuangan, Berbasis Balance Scorecard Pendekatan Teori, Kasus dan Riset Bisnis. Jakarta: Bumi Aksara.

Hansen, Dor R., Maryane, Mowen. (2009). Akuntansi Manajerial. Jakarta: Salemba Empat.

Hefrizal, Muhammad., Laelisneni. (2018). Analisis Metode Economic Value Added Untuk Menilai Kinerja Keuangan Pada PT. Unilever Indonesia. Jurnal Akuntansi dan Bisnis, Vol. 4 No. 1.

Kuncoro, Mudjarat. (2009). Metode Riset untuk Bisnis dan Ekonomi. Edisi 3. Jakarta: Erlangga.

Sawir, Agnes. (2009). Analisis Kinerja Keuangan dan Perencanaan Keuangan Perusahaan. Cetakan Kesepuluh. Jakarta: Gramedia.

Salaga Jakub, Bartosova Viera, Kicova Eva. (2015). Economic Value Added as a Measurement Tool of Financial Performance, Procedia Economics and 
Finance. Volume 26, Pages 484-489. https://doi.org/10.1016/S22125671(15)00877-1.

Subedi, M., Farazmand, A. (2020). Economic Value Added (EVA) for Performance Evaluation of Public Organizations. Public Organiz Rev 20, 613-630 (2020). https://doi.org/10.1007/s11115-020-00493-2 